\title{
HUBUNGAN PENGETAHUAN BANTUAN HIDUP DASAR TERHADAP TINGKAT MOTIVASI MAHASISWA DALAM MENOLONG PASIEN HENTI JANTUNG PADA MAHASISWA PRODI NERS TINGKAT III STIKES SANTA ELISABETH MEDAN
}

\author{
Mardiati Barus *(1) \\ Staff Pengajar STIKes Santa Elisabeth Medan
}

\begin{abstract}
Background : The knowledge of basic life assistance becomes a fundamental matter of handling victims suffering from cardiac arrest. With the knowledge of basic life assistance and supported by the motivation of rescuer in handling victims suffering from cardiac arrest, it is expected that the mortality rate of cardiac arrest incident frequently occurring particularly outside the hospital may be reduced significantly.

Goals : The research aimed to know the connection between the knowledge of basic life assistance and the motivation level of students in helping patients suffering from cardiac arrest in prodi ners level III students of STIKes Santa Elisabeth Medan.

Methods : The research design used the corelational descriptive method, with the number of samples being 75 respondents.

Result : The results of research showed that the knowledge of students on basic life assistance was good (100\%) and the level of motivation in helping patients suffering from cardiac arrest was high (100\%). From the results of Spearmen rank, the value of $p=0.000$ ( $p<0.05)$ and the correlation coefficient of 0.997 were obtained, meaning that there was a strong connection between the knowledge of basic life assistance and the motivation level of students in helping patients suffering from cardiac arrest in prodi ners level III students of STIKes Santa Elisabeth Medan.
\end{abstract}

Conclution : It is expected that students would maintain good knowledge of basic life assistance and their motivation would be increasingly higher to perform basic life assistance in patients suffering from cardiac arrest.

\section{Keywords: Knowledge, Basic Life Assistance, Motivation, Cardiac Arrest, Student}

\section{PENDAHULUAN}

Henti jantung atau cardiac arrest adalah keadaan dimana terjadinya penghentian mendadak sirkulasi normal darah karena kegagalan jantung berkontraksi secara efektif selama fase sistolik (Hardisman, 2014). Banyak hal yang mempengaruhi terjadinya henti jantung, penyebabnya antara lain penyakit kardiovaskular, kekurangan 
oksigen akut, kelebihan dosis obat, gangguan asam basa/elektrolit, kecelakaan, tersengat listrik, tenggelam, anesthesia dan pembedahan, dan syok (Gadar Medik Indonesia, 2016).

Henti jantung menjadi penyebab utama kematian di beberapa Negara. terjadi baik di luar rumah sakit maupun didalam rumah sakit. Diperkirakan sekitar 350.000 orang meninggal per tahunnya akibat henti jantung di Amerika dan Kanada. Perkiraan ini tidak termasuk mereka yang diperkirakan meninggal akibat henti jantung dan tidak sempat diresusitasi. Walaupun usaha untuk melakukan resusitasi tidak selalu berhasil, lebih banyak nyawa yang hilang akibat tidak dilakukannya resusitasi. Sebagian besar korban henti jantung adalah orang dewasa, tetapi ribuan bayi dan anak juga mengalaminya setiap tahun. Henti jantung akan tetap menjadi penyebab utama kematian yang premature, dan perbaikan kecil dalam usaha penyelamatannya akan menjadi

ribuan nyawa yang dapat diselamatkan setiap tahun ( Gadar Medik Indonesia, 2016).

Pada saat terjadi henti jantung, secara langsung akan terjadi henti sirkulasi. Henti sirkulasi ini akan dengan cepat menyebabkan otak dan organ vital kekurangan

oksigen. Pernafasan yang terganggu,misalnya tersengal-sengal merupakan tanda awal akan terjadinya henti jantung. Maka dari itu, bantuan hidup dasar menjadi

bekal mendasar untuk menyelamatkan jiwa seseorang

ketika terjadi henti jantung (Sudiharto \& Sartono, 2013).
Maka dari itu, bantuan hidup dasar menjadi bekal mendasar untuk menyelamatkan jiwa seseorang

ketika terjadi henti jantung (Sudiharto \& Sartono, 2013). Bantuan hidup dasar merupakan sekumpulan intervensi yang bertujuan untuk mengembalikan dan mempertahankan fungsi vital organ pada korban henti jantungdan henti nafas. Intervensi ini terdiri dari pemberian kompresi dada dan bantuan nafas (Hardisman, 2014).

Bantuan Hidup Dasar juga merupakan bagian dari pengelolaan gawat darurat medis yang bertujuan mencegah berhentinya sirkulasi atau berhentinya respirasi, memberikan bantuan eksternal terhadap sirkulasi dan ventilasi dari korban yang mengalami henti jantung atau henti nafas melalui Resusitasi Jantung Paru (RJP). Pemberian Resusitasi Jantung Paru harus dilaksanakan dengan cermat. Resusitasi Jantung Paru terdiri dari 2 tahap, yaitu Survei Primer (Primary survey), yang dapat dilakukan oleh setiap orang, Survei

Sekunder (Secondary Survey) (Sudiharto \& Sartono, 2013).

Bantuan hidup dasar tersebut dapat dilakukan oleh siapa saja bukan hanya tenaga kesehatan, tetapi dengan syarat orang tersebut telah memiliki pengetahuan dasar mengenai bantuan hidup dasar dan juga keterampilan dalam melakukan bantuan hidup dasar. Dimana pengetahuan itu adalah hasil tahu, dan ini terjadi setelah orang melakukan penginderaan terhadap suatu objek tertentu (Notoatmodjo, 2010).

Hal itu juga erat kaitannya dengan motivasi sang penolong 
dalam menolong korban yang mengalami henti jantung. Dimana motivasi juga sebagai pendorong utama bagi sang penolong dalam memberikan pertolongan pertama pada korban. Dengan adanya motivasi yang tumbuh dalam diri kita, kita semakin menyadari adanya dorongan untuk berbuat atau beraksi. (Sunaryo, 2013).

Menurut Stevenson (2001, dalam Sunaryo, 2013) , motivasi adalah semua hal verbal, fisik, atau psikologis yang membuat seseorang melakukan sesuatu sebagai respons. Sementara itu Sarwono (2000, dalam Sunaryo, 2013) tersebut dan tujuan atau akhir dari mengungkapkan bahwa motivasi menunjuk pada proses gerakan, termasuk situasi yang mendorong dan timbul dalam diri individu, serta tingkah laku yang ditimbulkan oleh situasi tersebut dan tujuan atau akhir dari gerakan dan perbuatan.

Jadi dengan pengetahuan bantuan hidup dasar atau basic life support yang didukung oleh adanya motivasi penolong untuk melakukan penanganan korban yang mengalami henti jantung, diharapkan angka kematian kejadian henti jantung yang sering terjadi terutama yang berada di luar rumah sakit dapat berkurang secara signifikan.

Berdasarkan survey awal yang dilakukan dari data yang terdapat di STIKes Santa Elisabeth Medan Tahun 2016 mahasiswa prodi Ners tahap akademik tingkat III telah

mendapatkan pendidikan dan pelatihan mengenai bantuan hidup dasar pada tahun 2014 dimana mahasiswa tingkat III masih menjalani semester II yang dibawakan oleh mahasiswa tingkat
IV tahun 2014. Jumlah mahasiswa sebanyak 75 orang dan saat peneliti melakukan observasi dan wawancara dengan mahasiswa Ners tingkat III diantaranya hanya sekedar tahu bahwa bantuan hidup dasar adalah pertolongan pertama yang dilakukan pada pasien yang kritis dan tidak mengetahui bagaimana tahapan dan teknik yang dilakukan pada saat melakukan bantuan hidup dasar. Hal ini membuktikan bahwa masih kurangnya pengetahuan mahasiswa ners tahap akademik tingkat III mengenai bantuan hidup dasar.

Dari uraian latar belakang di atas maka peneliti tertarik untuk melakukan penelitian dengan judul "Hubungan Pengetahuan Bantuan Hidup dasar Terhadap Tingkat

Motivasi Mahasiswa Dalam Menolong Pasien Henti Jantung Pada Mahasiswa Prodi Ners Tingkat III STIKes Santa Elisabeth Medan”.

\section{METODE PENELITIAN}

Penelitian ini menggunakan descriptif coretional. Teknik pengambilan sampel dalam penelitian ini menggunakan Total Sampling sebanyak 75 mahasiswa prodi ners tingkat III STIKes Santa Elisabeth Medan. Instrumen dalam penelitian ini menggunakan kuesioner untuk pengukuran variable independen yaitu pengetahuan bantuan hidup dasar sebanyak 25 pertanyaan dan variable dependen yaitu tingkat motivasi mahasiswa dalam menolong pasien henti jantung sebanyak 25 pertanyaan. Uji statistic dalam penelitian ini menggunakan Spearman rank (rho) dengan tingkat kepercayaan $95 \%$, bila $p$ value < 0,05 maka Ha diterima yang berarti ada hubungan. 


\section{HASIL DAN PEMBAHASAN}

Tabel 1. Distribusi Karakteristik Responden Berdasarkan Demografi Prodi Ners Tingkat III STIKes Santa Elisabeth Medan Tahun 2017

Berdasarkan di atas dapat diketahui bahwa umur mahasiswa prodi ners tingkat III STIKes Santa Elisabeth Medan yang paling banyak adalah 19-20 tahun sebanyak 35 orang $(46,7 \%)$ dan 21-22 tahun sebanyak 35 orang $(46,7 \%)$, sebagian kecil pada umur $>23$ tahun sebanyak 5 orang $(6,6 \%)$. Berdasarkan jenis kelamin, perempuan yaitu sebanyak 64 orang $(85,3 \%)$, sedangkan lakilaki sebanyak 11 orang $(14,7 \%)$.

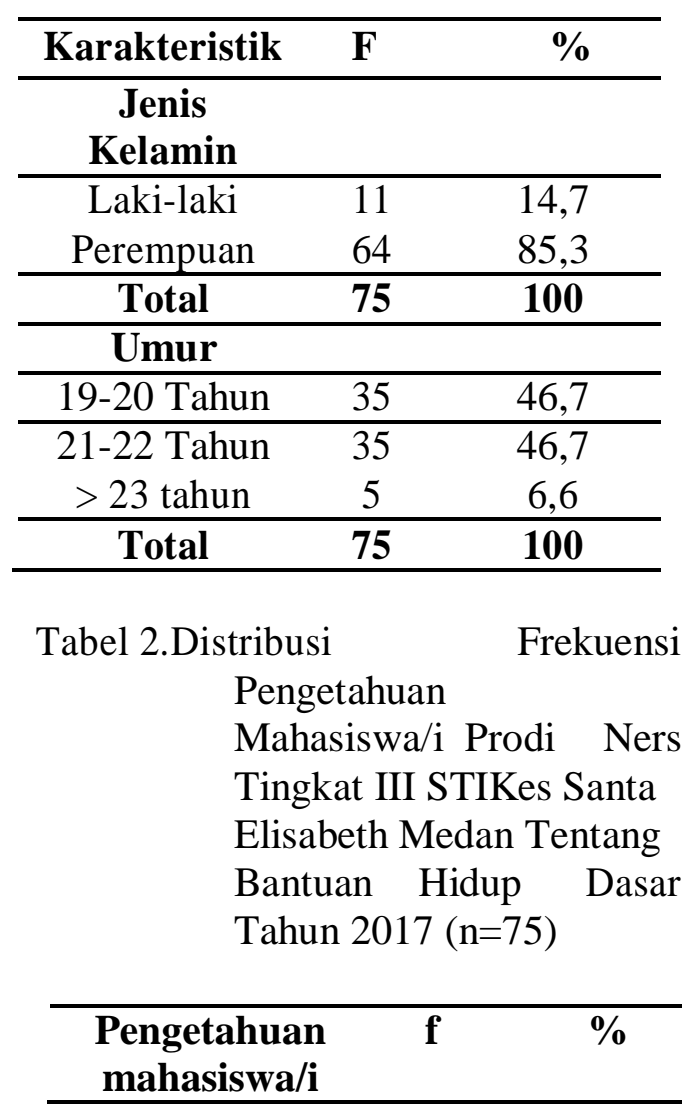

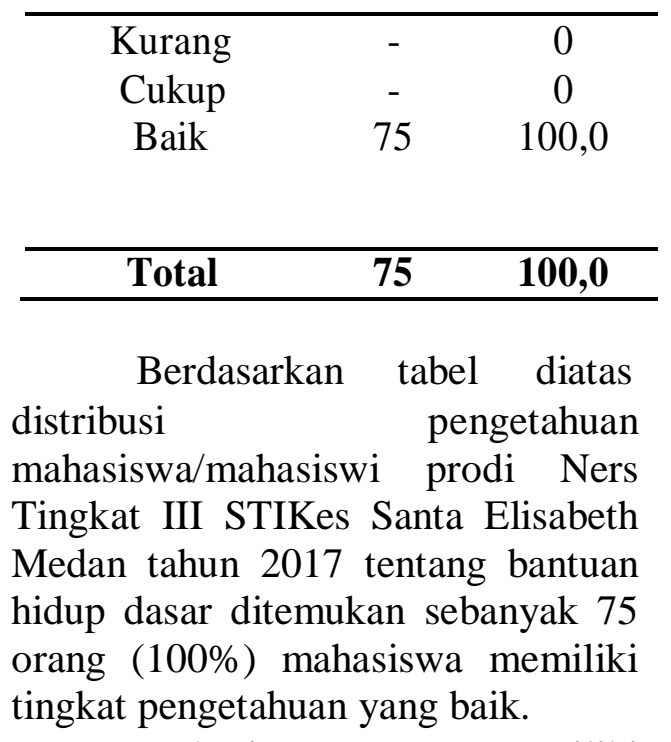

Mahasiswa memiliki pengetahuan yang tinggi karena pengalaman mereka yang pernah mengikuti beberapa seminar tentang bantuan hidup dasar, dan menurut peneliti faktor yang mempengaruhi pengetahuan responden tentang bantuan hidup dasar karena sesuai dengan kurikulum program studi ners bahwa mahasiswa prodi ners tingkat III memiliki mata kuliah keperawatan kritis dan keperawatan gawat darurat yang didalamnya juga membahas dan melatih mahasiswa melakukan bantuan hidup dasar. Dengan pengalaman mahasiswa yang pernah mengikuti pelatihan tersebut pengetahuan mahasiswa akan lebih baik dari pada mereka yang tidak mengikuti pelatihan bantuan hidup dasar. Pelatihan yang diikuti selama di bangku perkuliahan akan menambah pengetahuan mahasiswa tentang bantuan hidup dasar.

Tabel 3. Distribusi Frekuensi Tingkat Motivasi Mahasiswa Dalam Menolong Pasien Henti Jantung Pada Mahasiswa Prodi Ners Tingkat III STIKes Santa Elisabeth $\operatorname{Medan}(\mathrm{n}=75)$ 


\begin{tabular}{ccc}
\hline Motivasi & $\mathbf{f}$ & $\mathbf{\%}$ \\
\hline Rendah & 0 & 0 \\
Sedang & 0 & 0 \\
Tinggi & 75 & 100,0 \\
\hline Total & $\mathbf{7 5}$ & $\mathbf{1 0 0}$ \\
\hline
\end{tabular}

Berdasarkan tabel distribusi frekuensi tingkat motivasi mahasiswa dalam menolong pasien henti jantung pada mahasiswa prodi ners tingkat III STIKes Santa Elisabeth Medan mahasiswa ditemukan sebanyak 75 orang $(100 \%)$ memiliki tingkat motivasi yang tinggi.

Menurut Setiawati \& Dermawan (2008) salah satu jenis motivasi adalah motivasi yang dipelajari, Motivasi jenis ini akan ada dan berkembang karena adanya keingintahuan seseorang dalam proses pembelajarannya. Dalam hal ini, mahasiswa telah belajar tentang bantuan hidup dasar, maka mahasiswa tersebut akan termotivasi untuk lebih mempelajari dan membaca mengenai bantuan hidup dasar dan mengaplikasikannya pada saat menemui pasien yang mengalami henti jantung didalam rumah sakit maupun di luar rumah sakit .

\begin{tabular}{rrr} 
Tabel 4.Hubungan & \multicolumn{2}{r}{ Pegetahuan } \\
Bantuan & Hidup & Dasar \\
Terhadap & \multicolumn{2}{r}{ Tingkat } \\
Motivasi & \multicolumn{2}{c}{ Mahasiswa } \\
Dalam Menolong Pasien \\
Henti Jantung & Pada \\
Mahasiswa & Prodi & Ners \\
Tingkat III STIKes & Santa \\
Elisabeth Medan (n=75) \\
\hline & Peng & Mo \\
etah & tiv \\
uan & asi \\
\hline & &
\end{tabular}

\begin{tabular}{|c|c|c|c|c|}
\hline $\begin{array}{l}\text { Spe } \\
\text { ar }\end{array}$ & $\begin{array}{l}\text { Peng } \\
\text { etahu }\end{array}$ & $\begin{array}{l}\text { Correlatio } \\
\mathrm{n}\end{array}$ & & \\
\hline \multirow[t]{6}{*}{$\begin{array}{l}\text { ma } \\
\text { n's } \\
\text { rho }\end{array}$} & an & $\begin{array}{l}\text { Coefficie } \\
\text { nt }\end{array}$ & $\begin{array}{l}1,00 \\
0\end{array}$ & $\begin{array}{l}, 997 \\
* *\end{array}$ \\
\hline & & $\begin{array}{l}\text { Sig. (2- } \\
\text { tailed) }\end{array}$ & & ,000 \\
\hline & & $\mathrm{N}$ & 75 & 75 \\
\hline & $\begin{array}{l}\text { Moti } \\
\text { vasi }\end{array}$ & $\begin{array}{l}\text { Correlatio } \\
\mathrm{n} \\
\text { Coefficie } \\
\mathrm{nt}\end{array}$ & $\begin{array}{l}, 997 \\
* *\end{array}$ & $\begin{array}{l}1,00 \\
0\end{array}$ \\
\hline & & $\begin{array}{l}\text { Sig. (2- } \\
\text { tailed) }\end{array}$ & ,000 & \\
\hline & & $\mathrm{N}$ & 75 & 75 \\
\hline
\end{tabular}

**. Correlation is significant at the 0.01 level (2-tailed).

Berdasarkan hasil analisis korelasi variable dengan uji statistic Spearman rank (rho) yang telah didapatkan dari komputerisasi adalah 0.997 yang menyatakan hubungan yang sangat kuat antara variable independent yaitu pengetahuan bantuan hidup dasar dan dependen yaitu tingkat motivasi mahasiswa prodi ners tingkat III STIKes Santa Elisabeth Medan, sehingga dinyatakan hipotesis di tolak, yang berarti ada hubungan antara pengetahuan bantuan hidup dasar terhadap tingkat motivasi mahasiswa dalam menolong pasien henti jantung pada mahasiswa prodi ners tingkat

III STIKes Santa Elisabeth Medan. Hasil penelitian ini juga

mendukung hasil penelitian yang dilakukan oleh Thoyyibah \& Chayati (2014) tentang "pengaruh pelatihan bantuan hidup dasar pada remaja terhadap tingkat motivasi menolong korban henti jantung". Hasil dari penelitian menunjukkan adanya peningkatan motivasi setelah dilakukan pelatihan tentang bantuan hidup dasar yaitu sebelum pelatihan 
tingkat motivasi terbanyak adalah sedang sedangkan setelah pelatihan motivasi terbanyak adalah tinggi dan peneliti menyimpulkan bahwa tinggi rendahnya tingkat motivasi responden dalam menerapkan bantuan hidup dasar untuk menolong pasien yang henti jantung adalah karena adanya factor belajar. Proses belajar yang didapat responden melalui pelatihan bantuan hidup dasar dapat memberikan pengetahuan bagi responden dan

semakin banyak responden mempelajari dan mengetahui tentang bantuan hidup dasar maka ia akan lebih termotivasi untuk bertingkah laku sesuai dengan yang pernah dipelajarinya dan memanfaatkan fasilitas dan sarana yang ada seperti wifi, internet, dll.

Pengetahuan yang diperoleh dalam meningkatkan motivasi dapat diperoleh dari proses belajar dengan pemanfaatan media yang digunakan responden.Hal ini juga diungkapkan oleh Setiawati \& Dermawan (2008) bahwa salah satu jenis motivasi yang dilihat dari dasar pembentukannya adalah motivasi yang dipelajari yang berarti motivasi ini akan ada dan

berkembang karena adanya keingintahuan seseorang dalam proses pembelajaranya.

Menurut McClelland yang dikutip dan diterjemahkan oleh Sahlan Asnawi (2002), mengatakan bahwa dalam diri manusia ada dua motivasi, yakni motif primer atau motif yang tidak dipelajari, dan motif sekunder atau motif yang dipelajari melaui pengalaman serta interaksi dengan orang lain. Pada penelitian ini motivasi yang tinggi pada mahasiswa prodi ners tingkat III berasal dari pengalaman dan interaksi nya dengan orang lain selama melakukan pelatihan dan seminar mengenai bantuan hidup dasar. Melalui pelatihan tersebut yang dapat meningkatkan pengetahuan mahasiswa tentang bantuan hidup dasar akan mendorong mahasiswa untuk melakukan dan mengaplikasikan apa yang telah didapat selama pelatihan dan dilakukan dengan baik untuk mencapai hasil yang baik pula.

Pengetahuan seseorang akan mempengaruhi bagaimana seseorang tersebut termotivasi untuk bertingkah laku sesuai dengan yang pernah

dipelajarinya. Semakin banyak seseorang mempelajari atau mengetahui sesuatu hal maka ia akan lebih termotivasi untuk mengaplikasikan apa yang pernah ia pelajari. Dalam penelitian ini didapatkan pengetahuan seseorang akan sesuatu hal akan mempengaruhi tingkat motivasi seseorang tersebut dalam melakukan tindakan untuk mengatasi masalah tertentu. Sehingga, tinggi rendahnya motivasi juga selalu dijadikan indikator baik buruknya pengetahuan dan prestasi belajar seseorang. Sehingga, dapat disimpulkan bahwa ada hubungan pengetahuan bantuan hidup dasar terhadap tingkat motivasi mahasiswa dalam menolong pasien henti jantung pada mahasiswa prodi Ners tingkat III STIKes Santa Elisabeth Medan tahun 2017.

\section{KESIMPULAN DAN SARAN}

Tingkat

pengetahuan mahasiswa prodi ners tingkat III STIKes Santa Elisabeth Medan ditemukan secara keseluruhan (100\%) adalah baik.. Motivasi mahasiswa prodi ners tingkat III STIKes Santa Elisabeth Medan secara keseluruhan (100\%) dalam melakukan bantuan hidup dasar di rumah sakit maupun di luar rumah sakit adalah tinggi. Hasil analisis korelasi variable dengan uji statistic 
Spearman rank (rho) yang telah didapatkan dari correlation coefisien 0.997 yang artinya hubungan yang sangat kuat antara pengetahuan bantuan hidup dasar dan dan tingkat motivasi mahasiswa prodi ners tingkat III STIKes Santa Elisabeth Medan dalam menolong pasien yang henti jantung.

Diharapkan hasil penelitian ini dapat dijadikan sebagai pedoman ataupun panduan untuk lebih meningkatkan pengetahuan dan juga motivasi mahasiswa/i dalam menangani kondisi kegawat daruratan dan sekaligus mampu menjadi health provider khususnya pada kasus henti jantung.

Dan juga dapat di jadikan sebagai referensi tambahan dalam penelitian yang berhubungan dengan kejadian kegawat daruratan khususnya henti jantung. Dan juga diharapakan mahasiswa prodi ners tingkat III STIKes Santa Elisabeth Medan yang sudah memiliki pengetahuan yang baik tentang bantuan hidup dasar mampu mengaplikasikannya di lapangan dan mngeksplore pengetahuan mereka kepada mahasiswa dan prodi lain dengan aktif melakukan seminar dan kegiatan sederhana yang terkait dengan bantuan hidup dasar guna mewujudkan visi dan misi STIKes Santa Elisabeth Medan Prodi Ners dalam kegawatdaruratan jantung dan trauma fisik.

\section{DAFTAR PUSTAKA}

Aam, Riri. (2014). Pengetahuan Perawat Tentang Pemberian Bantuan Hidup Dasar Pada Pasien Henti Jantung Di Ruang Intensive CareRumah
Sakit Di Jakarta, (Online), (Diakses pada tanggal 6 Januari 2017).

Arikunto, Suharsimi. (2010). Manajemen Penelitian. Jakarta: Rineka Cipta.

Arikunto, Suharsimi. (2006). Prosedur Penelitian. Jakarta: Rineka Cipta.

Dal, Sarpkaya. (2013). Knowlegde and psychomotor skills of nursing students in North Cyprus in the area of cardiopulmonary

resuscitation, (online). (Diakses pada tanggal 21 Desember 2016).

Gloe, Donna S. (2005). Sheehy's Manual Of Emergency Care. United State Of America: $\quad$ Elsevier Mosby.

Hardisman. (2014). Gawat Darurat Medis Praktis. Yogyakarta: Gosyen Publishing.

Latif, Yusuf, dkk. (2015). Gambaran Pengetahuan Bantuan Hidup Dasar (BHD) Pada Mahasiswa Program Studi Ilmu Keperawatan Universitas Negeri Gorontalo, (Online). (Diakses pada tanggal 4 Januari 2017).

Lontoh, Kiling, dkk. (2013). Pengaruh Pelatihan Teori Bantuan Hidup Dasar Terhadap Pengetahuan Resusitasi Jantung Paru Siswa- 
Siswi SMA Negeri 1

Toili, (online). (Diakses pada tanggal 26 Oktober 2016).

Notoatmodjo, Soekidjo. (2005). Metodologi Penelitian Kesehatan. Jakarta: Rineka Cipta.

Promosi Kesehatan \& Ilmu Perilaku. Jakarta: Rineka Cipta. Metodologi Penelitian Kesehatan. Jakarta: Rineka Cipta.

Metodologi Penelitian

Kesehatan. Jakarta: Rineka Cipta.

Nursalam. (2013). Metodologi Penelitian Ilmu Keperawatan

Pendekatan Praktis. Edisi 3. Jakarta : Salemba Medika.

Panacea, Tim Bantuan Medis. (2012). Buku Panduan Basic Life Suport. Jakarta: EGC

Riyanto, Agus. (2013). Kapita Selekta Kuisioner Pengetahuan dan Sikap Dalam Penelitian Kesehatan. Jakarta : Salemba Medika.

Roifah, ifa. (2014). Metode Cardio Pulmonary Resuscitation Untuk Meningkatkan Survival Rates pasien
Post Cardiac Arrest, (Online), (Diakses pada tanggal 6 Januari 2017).

Sartono, dkk (2016). Basic Trauma Cardiac Life Suport. Bekasi: Gadar Medik Indonesia.

Setiawati \& Dermawan. (2008). Pendidikan Kesehatan. Jakarta: Trans Info Media.

Sudiharto, Sartono. (2013). Buku Panduan Basic Trauma Cardiac Life Suport. Jakarta: CV Sagung Seto.

Sunaryo. (2013). Psikologi Untuk Keperawatan. Jakarta: EGC.

Thoyyibah \& Chayati. (2014). Pengaruh Pelatihan Bantuan Hidup Dasar Pada Remaja Terhadap Tingkat Motivasi Menolong Korban Henti Jantung, (Online). (Diakses pada tanggal 22 Desember 2016).

Wawan, Dewi. (2011). Teori Dan Pengukuran Pengetahuan, Sikap, Dan Perilaku Manusia Dilengkapi Contoh Kuesioner. Yogyakarta : Nuha Medika. 